Dorota Kilańska ${ }^{1}$

Bożena Gorzkowicz $z^{2}$

Zofia Sienkiewicz $z^{3}$

Małgorzata Lewandowska ${ }^{4}$

Iwona Dominiak ${ }^{1}$

Wojciech Bielecki ${ }^{5}$

\title{
EVALUATION OF CHOSEN DETERMINANTS OF THE POSITIVE PRACTICE ENVIRONMENTS (PPE) AT POLISH NURSING WARDS
}

\author{
EWALUACJA WYBRANYCH DETERMINANTÓW POZYTYWNEGO ŚRODOWISKA PRACY \\ NA ODDZIAŁACH SZPITALNYCH W POLSCE
}

\author{
${ }^{1}$ Medical University of Lodz / Uniwersytet Medyczny w Łodzi, Łódź, Poland \\ Department of Social Nursing and Management in Nursing / Zakład Pielęgniarstwa Społecznego i Zarządzania w Pielęgniarstwie \\ ${ }^{2}$ Pomeranian Medical University / Pomorski Uniwersytet Medyczny, Szczecin, Poland \\ Faculty of Health Sciences / Wydział Nauk o Zdrowiu \\ ${ }^{3}$ Medical University of Warsaw / Uniwersytet Medyczny w Warszawie, Warszawa, Poland \\ Faculty of Health Sciences, Department of Social Nursing / Wydział Nauk o Zdrowiu, Zakład Pielęgniarstwa Społecznego \\ ${ }^{4}$ Medical University of Lodz / Uniwersytet Medyczny w Łodzi, Łódź, Poland \\ Department of Nursing Theory and Skills in Nursing / Zakład Teorii Pielęgniarstwa i Umiejętności Pielęgniarskich \\ ${ }^{5}$ Medical University of Lodz / Uniwersytet Medyczny w Łodzi, Łódź, Poland \\ Department of Social Pathology and Preventive Medicine / Katedra Medycyny Społecznej i Zapobiegawczej
}

\begin{abstract}
Background: At many Polish hospitals, insufficient attention is given to positive work environment. In many cases nurses, similarly to the representatives of other professional groups, are not provided with facilities or tools to perform their professional tasks in safe conditions. The aspects of recruitment and retention of employees are often ignored. The aim of this study has been to assess the chosen determinants of work environment of nurses in Poland using the concept of the Positive Practice Environments (PPE). Material and Methods: The survey was carried out from 2008 to 2011 among 1049 nursing students of 3 randomly selected public medical universities that provided nursing education at the graduate level of the Master of Science. All the people qualified for the study group were practising nurses or midwives. The Polish Nursing Association coordinated the project, obtained the tool, translated it and adjusted it to the Polish conditions. The areas covered in the survey were: a place of employment, selected physical and social elements influencing the work conditions, and biographical information. Results: Access to as many as 8 factors identified as attributes of friendly environments was found unsatisfactory by over $50 \%$ of the nurses. For the purpose of objective assessment, the results were compared with the results obtained in the group of nurses in England. Conclusions: The majority of the surveyed nurses were not satisfied with their work environments. Polish nurse managers should ensure that aspects of recognized attributes of friendly, positive practice environments for nurses are established to support nurses' satisfaction as a pre-condition for patients' safety. Med Pr 2016;67(1):11-19
\end{abstract}

Key words: nurses, workplace, occupational health, occupational environment, job satisfaction, patients' safety

\section{STRESZCZENIE}

Wstęp: W wielu polskich szpitalach mało uwagi poświęca się budowaniu pozytywnego środowiska pracy. Podobnie jak w przypadku innych zawodów w Polsce w miejscu pracy pielęgniarki często brakuje podstawowego wyposażenia, urządzeń i narzędzi niezbędnych do bezpiecznego wykonywania obowiązków zawodowych. Ponadto często nie są przestrzegane standardy przeprowadzania rekrutacji i utrzymania pracowników. Celem niniejszego badania była ocena środowiska pracy pielęgniarek w Polsce z wykorzystaniem koncepcji pozytywnego środowiska pracy (positive practice environments - PPE) i porównanie wyników z uzyskanymi w Wielkiej Brytanii w 2005 r. Materiał i metody: Badanie przeprowadzono w latach $2008-2011$ wśród 1049 studentów pielęgniarstwa 3 losowo wybranych publicznych uczelni medycznych, realizujących edukację pielęgniarek na poziomie studiów magisterskich. Wszystkie osoby zakwalifikowane do grupy badanej praktykowały jako pielęgniarki i/lub położne. Koordynatorem projektu było Polskie Towarzystwo Pielęgniarskie, które dostosowało kwestionariusz do polskich warunków po uzyskaniu prawa do jego przetłumaczenia. Do analizy włączono wyniki oceny środowiska pracy pielęgniarek i satysfakcji z niego w Polsce i Wielkiej Brytanii. Wyniki: Jako niezadowalający dla ponad 50\% pielęgniarek zidentyfikowano dostęp do 8 udogodnień w miejscu pracy, określanych jako atrybuty pozytywnego środowiska pracy. Wnioski: Większość badanych pielęgnia- 
rek nie była zadowolona $\mathrm{z}$ warunków środowiska pracy. Pielęgniarki-menadżerki powinny organizować pozytywne warunki pracy określone w PPE, ponieważ są one warunkiem satysfakcji pielęgniarek z pracy i zapewnienia bezpieczeństwa pacjentów. Med. Pr. 2016;67(1):11-19

Słowa kluczowe: pielęgniarki, miejsce pracy, medycyna pracy, środowisko pracy, satysfakcja z pracy, bezpieczeństwo pacjenta

Corresponding author / Autorka do korespondencji: Dorota Kilańska, Medical University of Lodz, Department of Social Nursing and Management in Nursing, Kościuszki 4, 90-419 Łódź, Poland, e-mail: dorota.kilanska@umed.lodz.pl

Received: April 11, 2015, accepted: August 3, 2015

\section{INTRODUCTION}

Work environment directly influences man's life and professional activity; it stimulates and organizes man's activity. In the late 1990's, most articles regarding the work environment of nurses focused on questions pertaining to the effect of its positive and negative determinants on the level of recruitment and retention of employees [1]. In many publications, the importance of the process of creating conditions fostering work performance and meeting expected standards was emphasized. Numerous studies indicate the impact of work environment not only on good performance but on making decisions to resign from one's job in favor of taking up a new profession or even at a cost of not taking up a new job whatsoever [2-4].

This approach has been a subject of interest of the World Health Organization (WHO) and the European Union for a long time. In cooperation with social partners and professional organizations, they have taken up actions aiming at promoting positive work environment policies for employees of the health care sector. It is believed that only such actions will enable an effective care of patients, which will help them return to work and everyday life, and contribute to a full development of economic potential. It is emphasized that all money invested in this sector will be recouped many times.

The studies show the role of an adequate number of staff members for the health and life of patients [5-9]. One of the highest indicators of the number of patients per nurse is observed in Poland. According to the Organization for Economic Co-operation and Development [10], there were 79 nurses looking after 10000 patients in the European Region and only 52 in Poland, with no data regarding caring personnel supporting nurses in their everyday work. The improvement of work conditions should therefore become a key action of all stakeholders involved in health care, primarily for politicians [11].
According to the definition by the International Council of Nurses (ICN), the Positive Practice Environments (PPE) are settings that support excellence and decent work. In particular, they strive to ensure the health, safety, and personal well-being of staff, support quality patient care and improve the motivation, productivity, and performance of individuals and organizations [12].

Positive Practice Environments are characterized by the following elements:

occupational health, safety and wellness policies that address workplace hazards, discrimination, physical and psychological violence and issues pertaining to personal security;

fair and manageable workloads and job demands/ stress;

arganizational climate reflective of effective management and leadership practices, good peer support, worker participation in decision-making, shared values;

healthy work-life balance;

equal opportunity and treatment;

opportunities for professional development and career advancement;

professional identity, autonomy, and control over practice;

job security;

decent pay and benefits;

safe staffing levels;

support and supervision;

open communication and transparency;

recognition programs;

access to adequate equipment, supplies, and support staff [12].

It should be emphasized that the assessment of work environment has a multi-aspect nature. Social and material aspects as well as interpersonal relations and taking up actions in favor of building this environment are the most important [13].

The terms 'practice environment' and 'work conditions' are used interchangeably in the majority of litera- 
ture. We intuitively define 'work conditions' as regarding issues directly associated with employment and work whereas 'practice environment' seems to be a broader concept. It covers determinants affecting both life and work. Moreover, both terms often include sets of elements and combinations that may change [14].

Positive work environment is characterized, first of all, by its influence on the organization functionality, individual work satisfaction, balance between professional and family lives, continuous development and organizational culture. Adverse work conditions mean definite costs resulting from the occurrence of medical errors, permanent stress and 'professional burnout' as well as absence or high turnover of staff which has a negative impact on care quality [14].

According to Wiskow et al. [14], positive work environment should also encourage continuous development and building trust in an employer (2010). Building an employee-positive work environment is therefore a key factor, from an employer's point of view too. To summarize previous considerations, the Positive Practice Environments (PPE) may be defined as follows: the PPE includes all the factors (incentives, motivators, facilities) which not only encourage taking up a job in the profession but motivate to prove a good performance at the quality level expected in this profession, allow to achieve a balance between work and life (well-being), and discourage thinking of giving up the job in the organizational unit or any job within the profession. These factors constitute an incentive system in the form of financial and non-financial motivators important to an individual and a counterbalance to making decisions about remaining employed or leaving the organization [12].

The aim of this study has been to assess the chosen determinants of nurses' work environment in Poland using the ICN concept of the Positive Practice Environment. The specific objective has been to evaluate satisfaction or dissatisfaction with the availability of facilities and to compare the results of the evaluation of the accessibility with the results in the United Kingdom (UK).

\section{MATERIAL AND METHODS}

\section{Population and sample}

The research was conducted with the use of the diagnostic survey method. The survey was carried out from 2008 to 2011 among 1049 nursing students of 3 randomly selected public medical universities that provided nursing education at the graduate level of the
Master of Science. All the people qualified for the study group were practising nurses or midwives. The Polish Nursing Association coordinated the project, obtained the tool from the Royal College of Nursing (RCN) with a permission to use it, translated it and adjusted it to the Polish conditions in 2007.

A pilot study was carried out for a group of 20 nurses, and afterwards some corrections were introduced in the original questionnaire. Taking into account a common lack of equipment for lifting and relocating patients, the questionnaire was supplemented with a set of questions related to bone and joint diseases (musculoskeletal disorders - MSDs) protection and prevention issues.

For statistical processing, 1045 nurses, out of 1049 nurses originally selected, were selected. The analysis of the collected data allows for the observation that nearly $70 \%$ of the participants were over 35 years old $53 \%$ of which were within the age range of 35-44 and almost $15 \%$ - within the age range of $45-54$ ), and only $12.7 \%$ nurses taking part in the survey were under 30 years old. The largest group consisted of nurses working at intensive therapy wards (nearly every fifth nurse). Every tenth nurse worked at a geriatric ward and nearly $10 \%$ of the employed in the primary health care represented school nurses, treatment rooms in the primary health care, etc.

The nurses employed in the home and family care made up $29.9 \%$ of the respondents. Nearly $10 \%$ of the nurses provided long-term care services, $8 \%$ of them worked at pediatric wards and $6.3 \%$ of them - in the gynecology and obstetric wards.

\section{Research tool}

The original research tool, used under the consent of the owners of the copyrights, was the questionnaire published in the Ball et al.'s article issued by the Royal College of Nursing in Great Britain [19].

The questionnaire consisted of 27 questions concerning the availability of such facilities as: catering facilities during the day, catering facilities at night, staff rooms for taking breaks, break times, staff transport, free car parking, access to parental leave, possibility to work part-time, possibility to job-share, possibility to self-roster, flexible work, access to term-time or school, holiday contracts, child-care vouchers or allowance, out of hours play scheme, holiday play scheme, workplace nursery or crèche, counseling services, careers guidance, clinical supervision, opportunity for staff training and development, career breaks, changing facilities, shower facilities, laundering service, depen- 
dent care leave, special leave. Questions were also asked whether employers talked to the respondents how they could help the respondents balance their work and life needs, and what facilities they needed or wanted.

Another tool indicated in the assumptions and used in the survey was the 'Health and Safety Executive (HSE) Management Standards Indicator Tool' questionnaire consisting of 35 closed-ended questions. This tool is commonly used in the United Kingdom for the assessment of professional distress of employees. The questionnaire contained questions about mobbing, physical and verbal abuse from patients, work overload, exposure to maltreatment at work and availability of support from a direct manager. The last component was the Clinical Outcomes in Routine Evaluation - Outcome Measure (CORE-OM) scale consisting of 34 closed-ended questions referring to the evaluation of the results of mental health and wellbeing measurement in the last 7 days after conducting the survey.
Selected results of the surveys carried out in Poland have been compared with the study on the PPE in the United Kingdom, which was carried out twice (in 2000 and 2005) by the Royal College of Nursing (RCN). For the purpose of this article, selected variables indicated in the RCN survey have been used as factors defining the PPE and are considered to be attributes of the Positive Practice Environments (PPE), which are presented in the Table 1.

\section{Ethical consideration}

Ethical approval from the Medical University of Lodz (RNN/221/08/KB) was obtained on 22nd April 2008. There was no known risk or potential harm for the participants. All participants were informed about the objectives of the study and written consent was obtained from them. Participation in the study was voluntary. The participants were informed that any evaluation report and subsequent publication would respect their confidentiality.

Table 1. Satisfaction of nurses with the availability of chosen determinants of the Positive Practice Environment (PPE) in Poland Tabela 1. Satysfakcja pielęgniarek $\mathrm{z}$ dostępu do wybranych determinantów pozytywnego środowiska pracy w Polsce

\begin{tabular}{|c|c|c|c|c|}
\hline $\begin{array}{l}\text { Facility in the workplace } \\
\text { Udogodnienie w miejscu pracy }\end{array}$ & $\begin{array}{l}\text { Respondents } \\
\text { Badani } \\
\text { [n] }\end{array}$ & \multicolumn{3}{|c|}{$\begin{array}{c}\text { Availability of facilities } \\
\text { Dostęp do udogodnień } \\
{[\%]}\end{array}$} \\
\hline $\begin{array}{l}\text { Catering facilities in the night / Dostarczanie produktów } \\
\text { żywnościowych w ciągu nocy }\end{array}$ & 763 & 55.8 & 38.3 & 5.9 \\
\hline $\begin{array}{l}\text { Staff rooms, e.g., for taking breaks / Pokoje socjalne dla } \\
\text { personelu, np. na czas odpoczynku }\end{array}$ & 838 & 46.4 & 5.1 & 48.5 \\
\hline Careers guidance / Przewodnik ścieżki kariery & 797 & 62.6 & 13.8 & 23.6 \\
\hline Counselling services / Usługi doradztwa zawodowego & 575 & 52.3 & 10.9 & 36.8 \\
\hline $\begin{array}{l}\text { Opportunity for staff training and development / Możliwość } \\
\text { rozwoju i szkolenia zawodowego }\end{array}$ & 804 & 52.7 & 5.6 & 41.7 \\
\hline Changing facilities / Szatnie/szafki dla pracowników & 761 & 60.3 & 25.1 & 14.6 \\
\hline Showering facilities / Prysznic dla pracowników & 786 & 64.5 & 9.2 & 26.3 \\
\hline Locker for belongings / Szafka na rzeczy osobiste & 821 & 38.6 & 5.7 & 55.7 \\
\hline
\end{tabular}




\section{RESULTS}

\section{Accessibility of the PPE determinants in Poland}

The results of the survey show that though over a half of the surveyed nurses have access to staff rooms and related facilities (64.5\%), more than $1 / 3$ of nurses (34.5\%) have no possibility to rest during the working day. Over a half of the surveyed nurses have no access to free parking spaces (54.2\%) and counseling services $(54.5 \%)$. Being entitled to days off in order to raise qualifications and participate in professional trainings has been reported by $61.8 \%$ of the nurses. Alarmingly, only $3 / 4$ of the nurses have been given access to lockers for personal belongings (75.2\%) and 59.4\% of them - to laundry services at their workplace. Every third nurse has to keep her overalls clean at her own cost.

Just a little more than $1 / 3$ of the nurses reported that their employers provided amenities at their workplace. It should be noticed, however, that a significant group of Polish nurses (8.2\%) are unaware of this fact.
The majority of the surveyed nurses reported that the employers did not make shower facilities available to them (55.4\%).

Though the majority of the nurses have their personal belongings secured by their employer, more than every fifth nurse (23.7\%) has to take care of them on her own account (Table 1).

A worker's satisfaction with the accessibility to the amenities mentioned in the Table 1 (i.e., a sense of comfort associated with safekeeping of personal belongings during a working day) is another aspect that may contribute to positive evaluation of the work environment. Eight factors indicated as the determinants of a positive environment have been considered unsatisfactory by over a half of the nurses (Table 1). Those 8 factors were: the possibility of having a meal during the day and night shift (58\% and 55.8\%, respectively), transport service to and from the workplace (49.5\%), access to counseling services at the workplace (52.3\%), possibility of professional career development (promotion, not

Table 2. Comparison of the availability of the chosen determinants of the PPE in Poland and United Kingdom

Tabela 2. Porównanie dostępu do wybranych determinantów pozytywnego środowiska pracy w Polsce i Wielkiej Brytanii

\begin{tabular}{|c|c|c|c|c|c|c|c|c|}
\hline \multirow{2}{*}{$\begin{array}{l}\text { Facility in the workplace } \\
\text { Udogodnienie w miejscu pracy }\end{array}$} & \multicolumn{2}{|c|}{$\begin{array}{l}\text { Respondents } \\
\text { Badani } \\
\text { [n] }\end{array}$} & \multicolumn{6}{|c|}{$\begin{array}{c}\text { Prevalence of facility } \\
\text { Występowanie udogodnienia } \\
{[\%]}\end{array}$} \\
\hline & UK & PL & UK & PL & UK & PL & UK & PL \\
\hline $\begin{array}{l}\text { Catering facilities in the night / Dostarczanie produktów żywnościowych } \\
\text { w ciągu nocy }\end{array}$ & 2759 & 938 & 26 & 5.2 & 63 & 90.4 & 11 & 4.4 \\
\hline $\begin{array}{l}\text { Staff rooms, e.g., for taking breaks / Pokoje socjalne dla personelu, } \\
\text { np. na czas odpoczynku }\end{array}$ & 2759 & 944 & 67 & 64.3 & 32 & 34.5 & 1 & 1.2 \\
\hline Careers guidance / Przewodnik ścieżki kariery & 2759 & 948 & 28 & 29.3 & 42 & 55.5 & 30 & 15.2 \\
\hline Counselling services / Usługi doradztwa zawodowego & 2759 & 930 & 62 & 54.5 & 20 & 38.0 & 18 & 7.5 \\
\hline $\begin{array}{l}\text { Opportunity for staff training and development / Możliwość rozwoju } \\
\text { i szkolenia zawodowego }\end{array}$ & 2759 & 950 & 93 & 61.8 & 6 & 34.6 & 1 & 3.6 \\
\hline Changing facilities / Szatnie/szafki dla pracowników & 2759 & 944 & 50 & 23.9 & 46 & 58.3 & 4 & 17.8 \\
\hline Showering facilities / Prysznic dla pracowników & 2759 & 939 & 39 & 36.4 & 57 & 55.4 & 4 & 8.2 \\
\hline Locker for belongings / Szafka na rzeczy osobiste & 2759 & 950 & 57 & 75.2 & 41 & 23.7 & 2 & 1.2 \\
\hline Uniform laundering service / Usługa prania odzieży roboczej & 2759 & 951 & 24 & 59.4 & 69 & 39.1 & 7 & 1.5 \\
\hline
\end{tabular}

UK - data from the survey in United Kingdom / dane z badania w Wielkiej Brytanii [15], PL - data from the authors' survey in Poland / dane z niniejszego badania w Polsce. 
necessarily vertical) $-62.6 \%$. Surprisingly, the lack of the possibility to have a meal at the workplace is not important for nearly $40 \%$ of the nurses. The access to staff training and personal development was unsatisfactory in the opinion of a half of the nurses (52.7\%), despite the fact that more than $60 \%$ of them had this kind of possibility.

\section{Satisfaction with the availability of the PPE determinants}

A large number of the surveyed nurses were not satisfied with access to changing facilities (60.3\%) and to shower facilities (64.5\%). More than a half of the respondents were not happy with the lack of access to uniform laundry service (50.1\%) (Table 2). Thus we may assume that these factors are important to nurses and may affect their work environment regarded as friendly.

The comparison of the results of this research with the RCN results suggests that good work conditions are important to nurses. This confirms the hypothesis that most nurses have access to various amenities which may be regarded as the ones accounting for a positive work environment, though not to a satisfactory level.

\section{DISCUSSION}

Various aspects of work environment were, and still are, in the area of interest of researchers of health care systems in Poland and worldwide. For many years, the effort has been made to draw managers' attention to the fact that in order to ensure care safety to patients, radical changes aiming at improvement of work conditions are necessary $[6,16]$.

The surveyed population is generally a drawback of the majority of such empirical trials. In many cases, it consists of several hundred nurses but surveys often refer to only one specialty or a single research problem and, consequently, the results of such surveys in general do not have an extrapolation value.

The PPE is a set of attributes perceived by an employee as important (including strong leadership, non-remuneration benefits - incentives and positive environment), increasing satisfaction with work and improving results of the provided care [12]. Although many factors related to work environment have been improved in the last 5 years, the workload has increased and almost a half of the nurses (46\%) expresses the opinion that, all in all, work environment is worse than it was five years ago [17].
Numerous studies indicate that the incentive system affects both job satisfaction and plans to give up one's job. Taking into consideration cultural differences and medicine advancement level, the incentive system in Poland may vary from what the American or British nurses report, for instance. In the studies carried out in the United Kingdom, the PPE determinants have been verified for several years. The studies assessed, among other things, access to day nurseries, access to shower at the workplace or facilities for keeping personal belongings, which was compared with the studies from the 1990s. Nurses, similarly to the representatives of other professional groups, want to perform their work well and therefore, they need conditions that provide them with minimum comfort.

Developing an incentive system that helps retain and recruit new staff is well documented in the literature, too. Although it seems right to consider remuneration to be the main motivator, numerous surveys have proven that non-financial incentives are most attractive to employees [18]. The essential factor indicated in the Blegen survey from 2009 is an adequate number of staff [19].

The PPE determinants were defined in the research carried out by the RCN in 2005. Those were, among others: career development and education opportunities, possibility to have a meal during the day or night shift, support of the clinical supervision, availability of staff rooms and related facilities to rest during the work shift, counseling services from superiors (clinical support), lockers for personal belongings, access to free parking space, improvements to work conditions (equipment), access to shower (to wash after work), career paths indicated by a mentor, access to uniform laundry service at the workplace, access to transport service to and from the workplace. When assessing the above mentioned determinants, it was proven that in the United Kingdom, in comparison with the year 2000, access to the facilities indicated by the nurses as the ones that determine the PPE had significantly decreased [15].

Among numerous analyzed variables, the lack of the possibility to have a meal at the workplace (when work time exceeds $8 \mathrm{~h}$ ) may have an adverse impact on health. In the United Kingdom, $60 \%$ of nurses are privileged to have meals during the working day (the drop from $70 \%$ in 2000) whereas in Poland as many as $90 \%$ of the surveyed nurses have no meal available during the working day (it is available just for 8.3\%) and this situation is the source of extreme dissatisfaction for nearly $60 \%$ of the nurses. Proportions were similar 
when nurses were asked about the availability of a meal during the night shift. In the United Kingdom, the proportion of nurses who have meals available during the night shift has decreased in comparison with the year 2000 from almost $50 \%$ to just over $40 \%$ [15].

In the distinctly feminized profession of nursing one of incentives to remain in the profession may be the availability of care services, parental leave or availability of day nursery services. The survey shows that $78 \%$ of the nurses are eligible for parental leave whereas in the United Kingdom, the increase from $48 \%$ in 2000 to $53 \%$ in 2005 was observed.

Another incentive which may help ensure child care is access to childcare vouchers (non-financial incentive). In the United Kingdom, 16\% increase in this kind of incentives offered by employers has been noticed. However, the level of satisfaction with access to this solution has decreased [15]. In Poland, almost every fifth nurse (17.5\%) has access to this form of help but $64.4 \%$ of nurses declare dissatisfaction with its availability.

Qualification raising and, through various forms, the Continuing Professional Development (CPD) are of importance in order to fulfill one's professional role. Access to education and professional skills development is perceived by nurses as an important factor of the evaluation of professional satisfaction [20]. They also consider their work socially useful and requiring qualification raising. Therefore, the lack of access to adequate education will lead to dissatisfaction with the job [18]. Thus providing nurses with professional development and continuing learning opportunities is a motivating factor [21] and contributes to retention of employees in the profession [22]. In Poland, there is no system to monitor the level of nurses' involvement in the long-life learning process but, in recent years, several thousands of nurses (12 570 as at 31 December 2012) have raised their professional qualifications up to the bachelor's degree [23].

A larger number of qualified nurses than of lower educated nurses means the reduction of adverse events and patient deaths [24] and an optimal number of nursing staff (including caring personnel) is closely associated with the reduction of the number of adverse events $[13,25]$.

Availability of a leave from work for qualification raising was reported by $23.9 \%$ of the nurses. However, every fourth nurse is not aware of such a possibility. In the United Kingdom, the proportion of nurses eligible for such a leave is bigger and amounts to $60 \%$, and $93 \%$ of British nurses are privileged with an opportunity of development and professional training. In Poland, this opportunity is available merely to $61.8 \%$ and $52.7 \%$ of nurses regard this fact as dissatisfactory. For $6 \%$ of nurses this is not important [15].

Overalls laundry services and access to a locker for personal belongings were assessed in the United Kingdom in 2005 for the first time. It was observed, among other things, that nearly $3 / 4$ of the surveyed nurses have no access to overalls laundry services [15]. In Poland, such laundry services are available to merely $39 \%$ of nurses, $1.5 \%$ of them do not know that overall laundry services remain their employer's responsibility.

Availability of transport services to and from the workplace is an important factor which may reduce the time of being at the employer's disposal and may impact the balance between work and private life. In Poland and in the United Kingdom, transport services of employees to and from the workplace is at a similar level (15\% in the UK and $15.6 \%$ in Poland). Access to free parking spaces for nurses in Poland is similar to the situation in the United Kingdom (54.2\%). A convergence also appears in determining one's career path: in Poland, it is a privilege for $29.3 \%$ of the survey target group [15].

Work amenities in a situation of staff shortage may solve the problem of workload. Therefore, employers should take care of making amenities available for their employees. While comparing the introduction of changes at the workplace by employers in Poland and the United Kingdom, one may notice differences in the significance assigned to this determinant. Access to and prospect of changes in Poland have been positively evaluated by every fifth nurse (23.9\%). In the United Kingdom, every second nurse reports that employers introduce changes (50\%) but $46 \%$ of nurses in the United Kingdom and 58.3\% of them in Poland express negative opinions on access to facilities available at the workplace [15].

Satisfaction with the availability of amenities is experienced by one-fourth of nurses in Poland (26.3\%). However, the level of satisfaction among British nurses has been significantly higher: it amounted to $65 \%$ in 2000 and has dropped by $15 \%$ to $50 \%$ [15]. A significantly larger number of nurses in Poland than in the UK ( $8.2 \%$ vs. $4 \%)$ are not aware that the availability of amenities at the workplace is possible [15].

A big problem with nurses' work in Poland is also maladjustment of work station with regard to ergonomics, e.g., unsuitable beds, couches without height 
adjustment or with mechanical height adjustment, low furniture, bad condition of equipment. Lack of modifications in this area may result in a feeling of excessive workload and pain in the osteoarticular system is reported as the main health problem among nurses in many surveys $[26,27]$.

Functional impairment of the vertebral column causes a lot of severe problems, impedes work, everyday well-being, social activities. These problems may influence performance of professional tasks. Availability of all sort of amenities that make work easier is important to nurses because disability lasting over one year is reported by almost every fifth nurse included in surveys both in Poland (17\%) and in the United Kingdom (19\%) [15].

In the above described health situation it seems essential that nurses have access to medical consultations even without referral. These factors may, at the same time, be an incentive to work in the organization. This survey has shown that $54.9 \%$ of nurses were given such an opportunity. Similar proportion of nurses in the United Kingdom reports availability of this service [15]. However, for over $40 \%$ of Polish nurses availability of medical consultations is strongly unsatisfactory.

\section{CONCLUSIONS}

In work environment of nurses in Poland, many attributes regarded as contributing to the creation of safe and positive work environment are not present. Therefore, in practice, the Positive Practice Environments (PPE) does not exist and employers, unfortunately, do not see the need to make any amenities available, even if a considerably big group of nursing staff is at risk of disability. Work environment in the Polish healthcare system does not foster work at a high level of patients' safety, good quality, and nurses' sense of satisfaction with performance at the workplace.

Polish nurse managers should recognize the determinants of a friendly environment for nurses and other medical staff members as a pre-condition for safety of the patients. The results provide an important insight for policymakers on how to improve the current situation in the healthcare system. Policymakers should consider the improvement of work environment as a method of retaining qualified nursing staff in Poland. Further research could provide deeper understanding of the essential factors and may be helpful in efforts to improve the situation and prevent nurses from leaving the job in Poland.

\section{REFERENCES}

1. Nolan M, Lundh U, Brown J. Changing aspects of nurses work environment: Comparison of perception in two hospitals in Sweden and the UK and implications for recruitment and retention if staff. J Res Nurs. 1999;4(3): 221-33, http://dx.doi.org/10.1177/136140969900400313.

2. Spence Laschinger HK, Leiter M, Day A, Gilin D. Workplace empowerment, incivility, and burnout: Impact on staff nurse recruitment and retention outcomes. J Nurs Manag. 2009;17(3):302-11, http://dx.doi. org/10.1111/j.1365-2834.2009.00999.x.

3. Toh SG, Ang E, Devi MK. Systematic review on the relationship between the nursing shortage and job satisfaction, stress and burnout levels among nurses in oncology/haematology settings. Int J Evid Bas Health. 2012;10(2):126-41, http://dx.doi.org/10.1111/j.1744-1609. 2012.00271.x.

4. Al-Dossary R, Vail J, Macfarlane F. Job satisfaction of nurses in a Saudi Arabian university teaching hospital: A cross-sectional study. Int Nurs Rev. 2012;59(3)3:42430, http://dx.doi.org/10.1111/j.1466-7657.2012.00978.x.

5. Person SD, Allison JJ, Keife CI, Weaver MT, Williams OD. Nurse staffing and mortality for Medicare patients with acute myocardial infarction. Med Care. 2004;42:4-12, http://dx.doi.org/10.1097/01.mlr.0000102369.67404.b0.

6. Rothberg MB, Abraham I, Lindenauer PK, Rose DN. Improving nurse-to-patient staffing ratios as a cost-effective safety intervention. Med Care. 2005;43(8):785-91, http://dx.doi.org/10.1097/01.mlr.0000170408.35854.fa.

7. Needleman J, Buerhaus PI, Stewart M, Zelevinski K, Mattke S. Nurse staffing in hospitals: Is there a business case for quality? Health Aff. 2006;25:204-11, http:// dx.doi.org/10.1377/hlthaff.25.1.204.

8. Patterson J. The effects of nurse to patient ratios. Nurs Times. 2011;107(2):22-5.

9. Duffin C. Nurse-to-patient ratios must increase to improve safety. Nurs Older People. 2012;24(4):6-7, http:// dx.doi.org/10.7748/nop2012.05.24.4.6.p8183.

10. Organization for Economic Co-operation and Development. Nurses (indicator). Paris: The Organization; 2014, http://dx.doi.org/10.1787/283e64de-en.

11. Aiken LH. Nurses for the future. N Engl J Med. 2011; 364:196-8, http://dx.doi.org/10.1056/NEJMp1011639.

12. Baumann A. Positive practice environments: Quality workplaces $=$ quality patient care. Information and action tool kit [Internet]. Geneva: International Council of Nurses; 2007 [cited 2015 Feb 21]. Available from: http:// www.icn.ch/images/stories/documents/publications/ ind/indkit2007.pdf. 
13. Spence Laschinger HK, Read E, Wilk P, Finegan J. The influence of nursing unit empowerment and social capital on unit effectiveness and nurse perceptions of patient care quality. J Nurs Adm. 2014;44(6):347-52, http://dx.doi.org/10.1097/NNA.0000000000000080.

14. Wiskow C, Albrecht T, de Pietro C. How to create an attractive and supportive working environment for health Professionals [Internet]. Copenhagen: World Health Organization Regional Office for Europe; 2010 [cited 2015 Feb 20]. Available from: http://www.euro.who. int/__data/assets/pdf_file/0018/124416/e94293.pdf.

15. Drösler S, Romano P, Wei L. Organisation for Economic Cooperation and Development health working papers No. 47. Health care quality indicators project: Patient safety indicators report 2009 [Internet]. Paris: The Organisation; 2009 [cited 2015 Feb 20]. Available from: http:// www.oecd-ilibrary.org/social-issues-migration-health/ health-care-quality-indicators-project_220112312723.

16. Dall TM, Chen YJ, Seifert RF, Maddox PJ, Hogan PF. The economic value of professional nursing. Med Care. 2009;47:97-104, http://dx.doi.org/10.1097/ MLR.0b013e3181844da8.

17. Atefi N, Abdullah KL, Wong LP, Mazlom R. Factors influencing registered nurses perception of their overall job satisfaction: A qualitative study. Int Nurs Rev. 2014;61(3):352-60, http://dx.doi.org/10.1111/inr.12112.

18. Blegen MA, Goode CJ, Spetz J, Vaughn T, Park SH. Nurse staffing effects on patient outcomes: Safety-net and nonsafety-net hospitals. Med Care. 2011;49:406-14.

19. Ball J, Pike G, Bradley M. At breaking point? A survey of the wellbeing and working lives of nurses in 2005 [Internet]. London: Royal College of Nursing; 2006 [cited 2015 Feb 20]. Available from: http://www. hrhresourcecenter.org/node/1417.

20. Van den Heede K, Lesaffre E, Diya L, Vleugels A, Clarke SP, Aiken LH, et al. The relationship between inpatient cardiac surgery mortality and nurse numbers and educational level: Analysis of administrative data. Int J Nurs Stud. 2009;46:796-803, http://dx.doi.org/10.1016/ j.ijnurstu.2008.12.018.

21. Kingma M. Nurses on the move: A global overview. Health Serv Res. 2007;42(3):1281-98.

22. Bonneterre V, Liaudy S, Chatellier G, Lang T, de Gaudemaris R. Reliability, validity, and health issues arising from questionnaires used to measure Psychosocial and Organizational Work Factors (POWFs) among hospital nurses: A critical review. J Nurs Meas. 2008;16:207-30, http://dx.doi.org/10.1891/1061-3749.16.3.207.

23. Central Register of Nurses and Midwives. [The analysis of the age structure of employed nurses and midwives acquiring the right to a pension] [Internet]. Warszawa: The Register; 2010 [cited 2015 Feb 22]. Available from: http://www.nipip.pl/attachments/article/1782/Wstepna. ocena.zasobow.kadrowych.pdf. Polish.

24. Aiken LH, Sermeus W, van den Heede K, Sloan DM, Busse R, McKee $M$ et al. Patient safety, satisfaction, and quality of hospital care: Cross sectional surveys of nurses and patients in 12 countries in Europe and the United States. BMJ. 2012;344:e1717.

25. Kanai-Pak M, Aiken LH, Sloane DM, Poghosyan L. Poor work environments and nurse inexperience are associated with burnout, job dissatisfaction and quality deficits in Japanese hospitals. J Clin Nurs. 2008;17(24):3324-9, http://dx.doi.org/10.1111/j.1365-2702.2008.02639.x.

26. Habibi E, Pourabdian S, Atabaki AK, Hoseini M. Evaluation of work-related psychosocial and ergonomics factors in relation to low back discomfort in emergency unit nurses. Int J Prev Med. 2012;3(8):564-8.

27. Jaromi M, Nemeth A, Kranicz J, Laczko T, Betlehem J. Treatment and ergonomics training of work-related lower back pain and body posture problems for nurses. J Clin Nurs. 2012;21(11-12):1776-84, http://dx.doi.org/ 10.1111/j.1365-2702.2012.04089.x.

This work is available in Open Access model and licensed under a Creative Commons Attribution-NonCommercial 3.0 Poland License / Ten utwór jest dostępny w modelu open access na licencji Creative Commons Uznanie autorstwa - Użycie niekomercyjne 3.0 Polska - http://creativecommons.org/ licenses/by-nc/3.0/pl. 